1 The ecological impact of oceanic island colonization - a palaeoecological 2 perspective from the Azores

3

4 Connor, S.E., van Leeuwen, J.F.N., Rittenour, T.M., van der Knaap, W.O., 5 Ammann, B. and Björck, S.

6

7

8

This is a draft version of a manuscript published in Journal of Biogeography 39:

9 1007-1023 (2012). Please note that there may be differences between this

10 version and the final published version. The authors will be happy to provide 11 copies on request. 
Strapline: Original Article

Running header: Palaeoecology of human colonization of the Azores

\section{The ecological impact of oceanic island colonization - a palaeoecological perspective from the Azores}

Simon E. Connor ${ }^{*}$, Jacqueline F.N. van Leeuwen ${ }^{2}$, Tammy M. Rittenour ${ }^{3}$, Willem O. van der Knaap ${ }^{2}$, Brigitta Ammann ${ }^{2}$ and Svante Björck ${ }^{4}$

${ }^{1}$ Centre for Marine and Environmental Research, University of the Algarve, 8005-139 Faro, Portugal, ${ }^{2}$ Institute for Plant Sciences and Oeschger Centre for Climate Change Research, University of Bern, Altenbergrain 21, 3013 Bern, Switzerland, ${ }^{3}$ Department of Geology, Utah State University, 4505 Old Main Hill, Logan, UT 84322, USA, ${ }^{4}$ Department of Earth and Ecosystem Sciences, Division of Geology Quaternary Sciences, Lund University, Sölvegatan 12, 223-62 Lund, Sweden

*Correspondence: Simon Connor, CIMA-FCT, Campus de Gambelas, University of the Algarve, Faro 8005-139, Portugal. E-mail: sconnor@ualg.pt

\section{ABSTRACT}

\section{Aim}

In many cases, human colonization drastically modified the ecosystems of remote oceanic islands before scientists arrived to document the changes. Palaeoecological records before and after human colonization provide insights into the original ecosystems and an assessment of subsequent human impact. We used pollen analysis to compare the impact of 15th century colonization of the Azores to that of natural disturbances such as volcanic eruptions and climate changes.

\section{Location}

Azores archipelago, Atlantic Ocean. 


\section{Methods}

Sediment records from three highland sites in the Azores (on the islands of Pico and Flores) were dated radiometrically and analysed palynologically. Pollen taxa were classified as native, endemic or introduced based on comparison with flora lists. Data were statistically zoned and temporal trends identified using detrended correspondence analysis.

\section{Results}

Human colonization of the Azores resulted in rapid, widespread, persistent vegetation changes on a scale unprecedented in the last 2700 years, detectable through the decline of dominant trees, spread of grasses and fire-tolerant species, introduction of exotic plants, evidence for grazing and fire, and changes to soils and moisture availability. During the same period, volcanic eruptions appear to have had more localized impacts on the vegetation, lasting 500-1000 years and favouring endemic taxa. The effect of late Holocene climatic changes on the highland vegetation of the Azores seems to have been minor. Palaeoecological data indicate that at least two plant species went extinct on Pico after human colonization and that some plants regarded as introduced were almost certainly part of the original flora of the islands. Despite a consistent signal of human impact, compositional differences between Juniperus brevifolia communities on Pico and Flores remained after colonization.

\section{Main conclusions}

Human colonization had a greater impact on the pristine vegetation of Pico and Flores than climatic changes and volcanic activity during recent millennia. The similarity between post-colonization changes on the Azores and other oceanic islands suggests a consistent pattern and scale to historical-era human impact on otherwise pristine ecosystems. These characteristics could be used to further elaborate biogeographical 
theory and direct conservation efforts towards species that appear most susceptible to human activity.

\section{Keywords}

Atlantic Ocean, conservation, Flores Island, human impact, island biogeography, palaeoecology, palynology, Pico Island, Portugal.

\section{INTRODUCTION}

Oceanic islands have provided the basis for much of our theoretical understanding of ecological processes (Whittaker et al., 2008). One of the first to recognize the significance of island biotas was Joseph Hooker (1867), who presented concepts of endemism, impoverishment and dispersal, which remain major themes for biogeographical research (Williamson, 1984; Berry, 1992). The relevance of Hooker's ideas today is attested by the recent formal incorporation of island age into the theory of island biogeography (Whittaker et al., 2008), the use of Quaternary climatic changes to explain patterns of diversity and endemism (Carine \& Schaefer, 2010), and the confirmation that some island plants went extinct through the "catastrophes" of human impact even before botanists arrived to document them (Hooker, 1867, p. 7; de Nascimento et al., 2009). Here we address the issue of historical human impact on oceanic island ecosystems, a theme of special importance in developing ecological theory (Whittaker et al., 2008) and sound conservation strategies (Fernández-Palacios et al., 2011).

Palaeoecological evidence has been used to recognize the first signs of human colonization and to evaluate human impact on islands from many corners of the globe (e.g. Flenley et al., 1991; Lawson et al., 2007, 2008; Prebble \& Wilmshurst, 2009; 
Ljung \& Björck, 2011). Just as the peculiar biotas of oceanic islands have led to a greater understanding of dispersal, invasion, endemism, extinction and evolution (to name a few), the effect of human colonization on previously pristine ecosystems may help us better differentiate human impacts from other kinds of disturbance (Prebble \& Wilmshurst, 2009). On the continents, such a differentiation is crucial for interpreting past ecological changes, as human impact remains a vague concept incorporating many scales, rates, processes, interactions and outcomes (Head, 2008; Connor, 2009).

Oceanic islands, because of their isolation, limited area and often recent colonization, provide distinctive opportunities to examine the ecological changes that accompanied human arrival, and in so doing shed light on human impacts in general.

Here we present new palaeoecological data from two islands in the Azores archipelago to address the following questions.

1. Has human impact homogenized Azorean vegetation across different islands?

2. Were endemic plant species more susceptible to human impact than other native species?

3. How did human colonization affect the biodiversity of the islands?

4. What was the scale of human impact in comparison to volcanic eruptions and climate changes?

\section{MATERIALS AND METHODS}

\section{Geographical setting}

The Azores are a group of oceanic islands that straddle the Mid-Atlantic Ridge, roughly $1600 \mathrm{~km}$ from Portugal and $1900 \mathrm{~km}$ from Newfoundland (Fig. 1). The nine islands are of volcanic origin, having arisen along sea-floor fracture zones as the Eurasian, African and North American tectonic plates rifted apart (Ferreira, 2005; Azevedo \& Ferreira, 
113

2006). The oldest rocks in the archipelago are found on the easternmost island, Santa Maria, and date to 8.12 million years ago (Azevedo \& Ferreira, 2006). The Azores are thus the youngest archipelago in the Macaronesian region, to which the archipelagos of Madeira, Canary Islands and Cabo Verde also belong (Fernández-Palacios et al., 2011). Owing to their volcanic origin, the islands of the Azores are pock-marked with craters and calderas. Soils are generally young andisols, formed under the humid climate on relatively recent lava flows and pyroclastic deposits (Dias, 1996). Peat deposits occur in depressions, around crater lakes and in vegetation communities where Sphagnum mosses play a prominent role (Dias, 1996).

The Azores experience an oceanic climate, with high humidity and cloud cover throughout the year, and an average temperature of $17.5^{\circ} \mathrm{C}$ at sea level. The main climatic controls over the Azores are the strength and position of the Azores Current, a branch of the Gulf Stream, and the Azores Anticyclone, a high-pressure cell that moves seasonally, bringing relatively dry and sunny conditions when it is positioned over the islands in summer (Schaefer, 2003). The western islands receive the highest average annual rainfall (e.g. Flores: $1716 \mathrm{~mm}$ at sea level), whilst the eastern islands have lower precipitation (e.g. Santa Maria: $775 \mathrm{~mm}$ ) and a more pronounced dry season (CLIMAAT Project, 2007). Rainfall increases dramatically with elevation, such that the highest parts of Flores and Pico may receive up to $5000 \mathrm{~mm}$ annually.

\section{Flora and vegetation}

Perhaps because of their isolation, modest age and oceanic climate, the Azores have a relatively small number of native plant species (197), of which about a third (70) are regarded as endemics (Schaefer, 2003). The majority of Azorean plants classified as endemic occur on all the islands, whereas the other archipelagos of Macaronesia are 
characterized by a large number of single-island endemics (Carine \& Schaefer, 2010). Recent genetic studies suggest that the Azores may harbour a considerable number of cryptic endemics, and therefore have rates of endemism similar to those of other Atlantic archipelagos (Schaefer et al., 2011). The Azorean flora comprises species from three main biogeographical lineages (Dias, 1996): a Tertiary Mediterranean element, a Plio-Pleistocene African element, and a Quaternary Euro-Siberian or Atlantic element. Despite the possibility of seed dispersal from the Americas, the Azores flora seems to have arrived primarily from the European and African continents via wind (potentially $40 \%$ of species) or migrating birds (58\%) (Schaefer, 2003).

When Portuguese mariners first encountered the Azores, they observed islands covered in impenetrable forests of Laurus azorica, Juniperus brevifolia, Prunus azorica and Morella faya (Costa, 1950), species which also feature prominently as macrobotanical fossils from the archipelago (Fries, 1968; Forjaz et al., 1970).

Historical descriptions indicate that each of these species, as well as Frangula azorica, Taxus baccata and Picconia azorica, dominated in different forests across the archipelago and suggest that there was no distinct zonation in relation to elevation (Dias, 1996; Schirone et al., 2010). Only the chronicles of Gaspar Frutuoso, published in 1589, bear witness to herbaceous vegetation on the high plains of Flores (Dias, 1996). By the 16th century, however, these herbaceous communities could have been affected by introduced grazing animals (the Azores have no native land mammals apart from bats).

\section{Human colonization}

It is likely that the Azores were already known to mariners at least 100 years before their official discovery by the Portuguese in the 15th century (Johnson, 1994), but there 
is no evidence for earlier colonization. The first Portuguese colony appeared on Santa Maria in 1439 and was followed by Flemish colonies on Faial in 1466 and Flores in 1472. Portugal later assumed control of the entire archipelago. According to Dias (1996), human impact on the vegetation occurred in three phases: (1) a pre-colonization phase in which a wide variety of domestic animals was released on the islands to sustain the anticipated human population; (2) an early, extractive phase in which forests were felled for construction, ship-building and charcoal production; and (3) a later, transformative phase in which the Azorean landscape was deforested and turned over to the production of exotic monocultures. As a consequence of these drastic human interventions, little native vegetation survives on the islands today and introduced plant species outnumber native species by a factor of three to one (Schaefer, 2003, 2005).

\section{Study sites}

Three sites were sampled after extensive reconnaissance on all the islands of the archipelago - Lagoa Rasa on the island of Flores, and Lagoa do Caveiro and 'Pico Bog' (field appellation for a mire north-east of Lagoa do Peixinho) on the island of Pico (Table 1; see also Fries, 1968; Azevedo \& Ferreira, 1998; Pugin \& Girardclos, 1998; Björck et al., 2006). The lakes of Rasa and Caveiro were selected to represent past vegetation changes on a relatively large scale, whilst Pico Bog was chosen to reflect changes on a more local scale (larger basins receive a greater component of regional pollen relative to smaller sites: see Moore et al., 1991). All three sites are craters situated in the highland vegetation zone in which Juniperus brevifolia and Erica azorica are the most important trees (Tutin, 1953).

Although all the Azores islands share many geographical features, the islands of Flores and Pico differ in key aspects: Flores reaches a maximum elevation of 915 m, 
while Pico is the highest mountain on Portuguese territory (2351 m); Flores receives more precipitation than Pico, hence most of Flores’ streams are perennial, while Pico's streams tend to be intermittent; Flores' last volcanic eruption occurred some 3000 years ago, while the last on Pico was in AD 1718-1720; and, in geological terms, Flores is around 2.15 million years old and situated entirely on the North American Plate, while Pico is the youngest member of the archipelago ( 0.27 million years) and rises from the Azorean microplate between the African and Eurasian Plates (Zbyszewski et al., 1963, 1968; Morrisseau \& Traineau, 1985; Dias, 1996; Azevedo \& Ferreira, 2006).

\section{Sampling and analysis}

Sediment cores were obtained from the centre of Lagoa Rasa in 1998 using a square-rod piston corer (Wright, 1967) and from the centre of Lagoa do Caveiro and Pico Bog in 2001 using a Russian corer (Björck et al., 2006). Coring continued until an impenetrable layer (presumably bedrock or thick tephra) was reached; each core therefore represents the sediment accumulated since a major eruption. Pre-eruption sediments were also cored from the margin of Lagoa do Caveiro. Samples of $1 \mathrm{~cm}^{3}$ were extracted from the cores and pretreated according to standard palynological methods, including the addition of Lycopodium spore tablets to determine pollen concentrations (Moore et al., 1991). Pollen was identified at 400× magnification with reference to Reille (1992, 1995 \& 1998) and reference material held at the Portuguese Institute of Archaeology (IPA). Percentage pollen diagrams were created from a sum of all terrestrial pollen taxa, including identifiable fern spores. Monolete fern spores (i.e. Polypodiales spores lacking the perine required for precise identification), Cyperaceae and aquatic taxa are excluded from the pollen sum, as are fungal spores indicative of 
212

213

grazing (van Geel \& Aptroot, 2006). Data were plotted using Tilia programmes (Grimm, 2004).

To determine whether human colonization caused the vegetation of the two islands to become more similar, we analysed percentage pollen data using detrended correspondence analysis (DCA) in the program PC-ORD 4.25 (McCune \& Mefford, 1999). Because DCA axes can be interpreted in terms of species turnover (Gauch, 1982), the analysis forms a basis for assessing ecological responses to both human impact and other 'natural' disturbances, such as volcanic eruptions indicated by tephra layers or climate changes recorded in other proxies (Björck et al., 2006).

To assess the effect of human impact on endemics in relation to other species, we classified the identified pollen taxa into 'endemics', 'native' and 'introduced' taxa (Table 2) with reference to their pollen morphology and the flora checklist of Silva et al. (2010 - plant taxonomy in this paper follows this checklist). Prior to analysis, taxa listed as 'introduced' occurring frequently prior to colonization were added to the 'native' category where their pollen representation suggested it was valid to do so (van Leeuwen et al., 2005). Any taxa that represented plant species that fell into more than one category were removed from the analysis, along with long-distance transported pollen produced by wind-pollinating species widespread on neighbouring continents. We then calculated two pollen sums based on the remaining taxa, one including the dominant taxon, Juniperus brevifolia, and one without.

We adopted the existing age-depth model for the Lagoa do Caveiro record (Björck et al., 2006) and formulated age-depth models (Fig. 2) for the other sites based on the accelerator mass spectrometry (AMS) radiocarbon dates listed in Table 3 and calibrated using CALIB 6.0.2 (Stuiver \& Reimer, 1993) and CALIBOMB (Reimer \& Reimer, not dated). Pre-impact and post-impact phases were identified independently 
237

238

239

240

241

242

243

244

245

246

247

248

249

250

251

252

253

254

255

256

257

258

259

260

261

through pollen zonation (binary splitting by information content), with statistical significance of the zones assessed using the 'broken stick' model (Bennett, 2008). We then calculated pollen accumulation rates for pre-impact and post-impact assemblages in order to determine pollen diversity using the method described by van der Knaap (2009). For comparison, percentage-based diversity estimates were produced in PSIMPOLL 4.26 (Bennett, 2008).

\section{RESULTS AND INTERPRETATION}

According to the multiproxy study of Lagoa do Caveiro (Björck et al., 2006), the central core $(0-488 \mathrm{~cm})$ covers approximately the last $4900 \mathrm{cal}$. yr BP (calendar years before AD 1950). The marginal core of pre-eruption sediments (to $614 \mathrm{~cm}$ ) extends this record back to approximately 6000 cal. yr BP (Björck et al., 2006). Both the Pico Bog (570 cm) and Lagoa Rasa $(331 \mathrm{~cm})$ records commence at approximately 2700 cal. yr BP (Fig. 2), corresponding to the most recent volcanic activity on Flores (Morriseau \& Traineau, 1985) and the inferred timing of the Caveiro-1076 volcanic eruption on Pico Island (Björck et al., 2006).

As our primary objective is to analyse the changes wrought by island colonization, each of the pollen diagrams has been subdivided into two statistically significant assemblage zones, termed 'pre-impact' and 'post-impact' phases (Figs 3-5). Other statistically significant zone boundaries are indicated on the diagrams, although the reduction in variance associated with these additional zones is lower. The boundary between pre-impact and post-impact phases, according to the age-depth models, falls at approximately 490 cal. yr BP for Lagoa Rasa (188 cm), 410 cal. yr BP for Lagoa do Caveiro $(137.5 \mathrm{~cm})$ and $385 \mathrm{cal}$. yr BP for Pico Bog $(205 \mathrm{~cm})$. These ages agree with the colonization history of the islands, given the uncertainties in age modelling and the 
fact that zone boundaries record statistically significant changes rather than the first signs of change.

In interpreting pollen records, it is important to bear in mind a number of inherent limitations. Pollen data are biased by production (different plant species release different quantities of pollen), taphonomy (some pollen taxa preserve poorly in sediments) and taxonomic resolution (pollen types usually represent several plant species), amongst others (Moore et al., 1991). The pollen production of native angiosperms on oceanic islands may be quite low (Collins \& Bush, 2011), perhaps due to the prevalence of animal-mediated pollination. Some taxa may only be detected where source plants occur very close to the site of deposition, especially those with specialized pollination mechanisms (e.g. Orchidaceae, Viola). In the case of the Azores, pollen taphonomy is a special problem. Laurus azorica, formerly the dominant tree at low to middle elevations, and Hedychium gardnerianum, a widespread invasive species, produce pollen that preserve poorly in sediments and tend to disintegrate during laboratory treatment (S. Connor, unpublished data). Laurus azorica pollen also lacks the surface ornamentation characteristic of other Lauraceae pollen (see Reille, 1992, 1995 \& 1998), complicating its identification in fossil sediments.

Problems of pollen-taxonomic resolution are limited on the Azores because of the relatively low number of plant species present on the islands. The likelihood of pollen arriving from the continents is also low, although wind-dispersed pollen types such as Alnus may travel long distances (Collins \& Bush, 2011). The level of taxonomic precision is indicated by the taxon names adopted in the text and figures. For example, Juniperus brevifolia represents only that plant species as it is the only Azorean plant to produce Juniperus pollen, Rumex obtusifolius-type includes all species that produce the same pollen type as $R$. obtusifolius (i.e. $R$. obtusifolius subsp. 
287

288

289

obtusifolius and R. crispus on the Azores), and Asteraceae subfamily Asteroideae represents Azorean species within that group except for those with morphologically distinct pollen, such as Bellis-type (representing Bellis azorica on Pico and Flores) and Pericallis-type (representing Pericallis, Senecio and Solidago species).

\section{The pre-impact phase}

The most obvious feature of pre-impact assemblages is the prevalence of pollen from the endemic Juniperus brevifolia at all sites (Figs 3-5). Juniper pollen is more abundant in the Lagoa Rasa record than the Lagoa do Caveiro record, while Pico Bog records the lowest proportions. The Lagoa do Caveiro juniper curve stands out for its high degree of variability. Episodic reductions in Juniperus brevifolia pollen are accompanied by increases in certain herbaceous taxa (e.g. Angelica lignescens, Ranunculus cortusifoliustype, Asteraceae subfamily Cichorioideae, and monolete fern spores) and geochemical indicators of lowered lake levels (Björck et al., 2006). We assume that these reductions reflect changes in pollen source-area controlled by water level in this shallow basin, rather than major vegetation changes. This interpretation is supported by the presence of juniper stomata during these phases and the absence of variations of similar magnitude in the Pico Bog record collected nearby.

Lagoa Rasa on Flores records a greater proportion of Myrsine africana, Picconia azorica and Viburnum treleasei in pre-impact assemblages compared to the two Pico records, which contain more Hedera azorica, Ilex perado ssp. azorica, Morella faya, Ericaceae and various herbaceous taxa. This may suggest that an open vegetation structure prevailed around the high-elevation sites on Pico, while Lagoa Rasa, situated at a lower elevation, was probably surrounded by denser Juniperus brevifoliadominated vegetation. The importance of Euphorbia stygiana in this vegetation zone 
312 (Tutin, 1953) is indicated by the frequent occurrence of Euphorbia pollen. Laurisilva

313 (Laurus azorica-dominated forest) may have also been present, but is not directly

314 recorded palynologically. Certain plant distribution patterns on the Azores today

315 apparently existed in the pre-impact phase, including the presence of Arceuthobium

316 azoricum and Daphne laureola on Pico but not on Flores (see Silva et al., 2010).

317 Each of the pollen records represents vegetation changes since a major eruption

318 or series of eruptions. This makes it possible to infer some characteristics of post-

319 disturbance ecological succession in these presumed pristine ecosystems. On Flores, a

320 pioneer community with Juniperus brevifolia, Ericaceae, Poaceae, Asteraceae and

321 Selaginella kraussiana appeared around Lagoa Rasa after the eruption; Culcita

322 macrocarpa and Myrsine africana gradually replaced some of these taxa over a period

323 of 500-1000 years. The indication of juniper as a pioneer agrees with vegetation

324 studies of recent lava flows on Terceira (Elias \& Dias, 2004). On Pico, the earliest

325 pollen assemblages from Lagoa do Caveiro are dominated by herbs, especially Angelica

326 lignescens, Anagallis, Hypericum foliosum-type and various Asteraceae, with Ilex

327 perado ssp. azorica and Juniperus brevifolia peaking prior to a series of major eruptions

328 around 5150-5200 cal. yr BP (Björck et al., 2006). After this event, the record shows a

329 distinct peak in Ericaceae (Erica azorica), Hypericum and Poaceae, succeeded by

330 assemblages like those recorded before the eruptions, and followed by Juniperus

331 brevifolia dominance. A very similar succession appears at the beginning of the Pico

332 Bog record (albeit with more Euphorbia and less Poaceae), indicating a consistent post-

333 eruption shift from herb- and shrub-dominated communities to greater forest cover. All

334 three pollen records suggest that Myrsine africana and Culcita macrocarpa are late-

335 successional species. 
Similar vegetation successions might be expected following each of the

eruptions that deposited subsequent tephra layers in the sediments of Lagoa do Caveiro and Pico Bog. However, a consistent relationship between these tephras and vegetation change is hardly evident. Vegetation succession following major eruptions at the base of each core is clearly picked out by DCA axis 2 (Figs $6 \&$ 7), but nothing similar is observed following each of the tephra layers. Apart from a dilution effect on pollen concentrations, the only observable impact of these tephras is a localized spike in endemic taxa at Pico Bog (Fig. 6). There is no indication that the pyroclastic material ejected during these smaller eruptions was sufficient to reset the successional clock.

\section{The post-impact phase}

The next phase in the vegetation history of the Azores begins around $400 \mathrm{cal}$. yr BP. Even by this time there were signs of early human interventions, probably as a consequence of the deliberate introduction of exotic mammals. Grasses (Poaceae) and bracken (Pteridium aquilinum) seem to have increased the earliest, followed by Erica azorica, an endemic that appears to have benefited from the decline of Juniperus brevifolia communities, and Morella faya, a native tree that probably replaced Laurus azorica at lower elevations (Figs 3-5). Previously abundant herbs (represented by Angelica lignescens, Asteraceae subfamily Cichorioideae, Euphorbia and Ranunculus cortusifolius-type) diminished and a suite of introduced taxa appeared (e.g. Castanea sativa, Ligustrum, Vitis, Plantago lanceolata, P. major-type, Cerealia-type and Zea mays; Hydrangea macrophylla and Cryptomeria japonica appeared later). As the replacement of native Azorean vegetation by agriculture and invasive introduced species such as Pittosporum undulatum has been less at higher elevations compared to the lowlands, the full extent of post-colonization plant invasion is probably not 
361

represented in the pollen diagrams. Pastoralism on the islands is attested by the appearance of spores produced by dung-inhabiting fungi (Podospora and Sporormiella) and the historically documented conflagrations that were used to open these pastures are recorded clearly in the charcoal record from Lagoa Rasa (Fig. 3). Fire does not seem to have been prevalent at any time around the high-elevation sites on Pico, perhaps because of low plant biomass.

\section{Has human impact homogenized the vegetation across different islands?}

The transition from pristine to human-impacted ecosystems is most vividly expressed in Fig. 7. DCA axis 1 is interpreted as representing moisture availability: strong negative correlates include Asteraceae, Apiaceae and Euphorbia; strong positive correlates are moisture-loving taxa such as Trichomanes, Viburnum and Frangula. DCA axis 2 is related to forest cover: strong negative correlates include forest taxa such as Juniperus, Picconia and Viburnum, while positive correlates are light-demanding herb taxa, for example Poaceae, Anagallis and Pteridium.

Pre-colonization variations probably relate to available soil moisture (axis 1), which is a limiting factor on the young, high porosity soils of volcanic islands (MuellerDombois, 1975). In the post-impact phase, however, the pattern is distinctly different, indicating a trajectory towards lower forest cover (axis 2) and more available moisture (axis 1). A separate DCA of the pre-impact samples from all sites (not shown) proved that the pattern expressed by the DCA axis 1 is robust (correlation between the two sets of results is $r=0.99, P<0.001)$. At least as far as these pollen data are concerned, the hypothesis that human impact has homogenized the vegetation on Pico and Flores is not supported. We hasten to add that this conclusion applies only to the highland vegetation 
of these islands and a very different result could be expected in the coastal lowlands or on the more densely populated parts of the archipelago.

One striking feature of the pollen diagrams is the post-impact explosion of Sphagnum spores, which are scarcely recorded before human impact. Sjögren (1973) remarked on how widespread burning and deforestation on the islands has led to the rapid expansion of Sphagnum blanket peat, causing edaphic changes that effectively prevent regeneration in remnant plant communities. Blanket mire formation can be initiated when burning forms a layer of fine hydrophobic particles on the soil surface, reducing percolation, and/or when deforestation decreases the leaf-area index, reducing evapotranspiration (Moore, 1975). The palaeoecological data provide support for Sjögren's argument in the post-impact abundance of Sphagnum spores, higher charcoal concentrations and the suggestion of higher available moisture and lower tree cover. There is a possibility that the role of Sphagnum in Azorean plant communities has increased markedly since human colonization or that human activities have somehow promoted sporulation. Similar post-colonization Sphagnum expansions are also recorded on other oceanic islands (e.g. Faroe and Galápagos) and may constitute a general trend initiated by hydrological changes, fire, deforestation, grazing and loss of soil fertility (Lawson et al., 2007).

\section{Are endemic species more susceptible to human impact?}

In theory, human colonization could have a stronger impact on plants endemic to oceanic islands, because in pristine ecosystems the plants have evolved or persisted in the absence of novel or exotic disturbances. Hence the proportion of non-endemic native species may increase relative to endemics in the post-colonization period. Comparison of pollen from exclusively endemic and native taxa (Fig. 6) shows that 
410

411

human impact caused a crash in the ratio of endemics to natives, consistent with this hypothesis. However, our pollen data are clearly dominated by Juniperus brevifolia, which is both an abundant pollen producer and one of the species worst affected by colonization. If Juniperus is excluded from the calculations, a very different pattern is observed - a slow and gradual decline in the representation of endemic taxa in the pollen records, evident even before human contact. The pattern is less pronounced for the Pico Bog record where responses to local eruptions are also evident, but the rate of decline at all sites is quite similar (Fig. 6).

While human impact changed the relative proportions of taxa within the endemics group, the relatively constant rate of decline and its representation at all three sites suggests that a long-term process is at work. Endemics may be better than other species at colonizing bare rock in the aftermath of a major volcanic eruption. In other words, "volcanism resulted in superior adaptation of many native species to extreme edaphic conditions existing on volcanic rockland” (Mueller-Dombois, 1975, p. 364). Thus endemics gain the upper hand on skeletal soils formed directly after a major eruption, but subsequent ecological succession and soil formation lead to their gradual replacement by other native species. The slow rate of change and high degree of recent landscape modification on the Azores mean that it may be difficult to detect this process today.

\section{How has biodiversity been affected by human impact?}

One way of assessing changes in biodiversity from island colonization is through estimates of palynological diversity. Such estimates are only indirectly related to floristic diversity, being biased by pollen taxonomy, pollen representation and vegetation structure (Odgaard, 1999). Percentage-based diversity estimates are strongly 
influenced by evenness (Odgaard, 1999) and in our dataset $72 \%$ of the variance in such estimates is explained by evenness (measured by the 'probability of interspecific encounter’; see van der Knaap, 2009). We attempted to reduce bias in diversity estimates by ensuring taxonomic consistency between the two analysts and adopting an estimation method based on pollen accumulation rates (PAR) instead of percentages. PAR-derived diversity estimates (Fig. 6) are not influenced by palynological evenness, but are susceptible to the adopted age-depth models and variations in pollen concentrations. For example, diversity peaks around 1700-1350 cal. yr BP at Lagoa do Caveiro are probably artefacts related to high sedimentation rates and sediment reworking, which clearly occurred in the Caveiro record (Björck et al., 2006). Despite this, the clear and recent increase in pollen diversity at the two lake sites is likely to represent the introductions of exotic plants to the archipelago since colonization - the ‘transformative phase’ of Dias (1996). Diversity estimates for native taxa alone also exhibit a small post-impact increase, which could be attributed to changes in vegetation structure (deforestation), permitting more pollen from longer distances to enter the lakes. Diversity around Pico Bog, which has a smaller pollen source-area, appears to have crashed since island colonization.

One conclusion that could be drawn from these estimates is that human impact on the Azores caused diversity to decline in local settings, while on the regional scale represented by the lake records, exotic introductions and deforestation increased the number of taxa detectable palynologically.

Plant extinctions are a feature common to many oceanic islands following human colonization (Table 4). Ophioglossum lusitanicum spores appear in the Lagoa do Caveiro and Pico Bog records, but this species is not to be found in the recent flora of Pico (Silva et al., 2010). Ophioglossum azoricum is likewise recorded in the Lagoa 
460

461

462

463

do Caveiro sediments, but not in the flora. These ferns produce large, morphologically distinct spores, so significant long-distance dispersal is unlikely and identification is assured. Unless these plants have been overlooked by botanists, it is probable that they have become locally extinct on Pico at some time since human colonization. Another species that has become extinct from several Azorean islands is Taxus baccata (Schirone et al., 2010). We were unable to find any Taxus pollen in the three pollen records, so it is unlikely that $T$. baccata trees grew around these study sites during the late Holocene.

An important consideration for the study of island biodiversity and conservation is the accurate determination of whether species are introduced or native (van Leeuwen et al., 2008; Kueffer et al., 2010). Fossil evidence is one of the main criteria for assigning native status (Webb, 1985). Palaeoecological evidence for Selaginella kraussiana, a plant previously listed as introduced, demonstrated the species to be native to Flores and Pico (van Leeuwen et al., 2005). The plant is now considered native to all the Azorean islands (Schaefer, 2005; Silva et al., 2010).

Using the same approach, we can add Illecebrum verticillatum and at least one Persicaria species to the taxa likely to be native to Flores and Pico. Just as some native species went extinct from island floras before being recorded (Hooker, 1867; de Nascimento et al., 2009), other native species were incorrectly recorded as introduced, perhaps because of their occurrence in disturbed areas or their introduced status on islands in other parts of the world (Schaefer, 2003; van Leeuwen et al., 2008). Three other pollen taxa require further study. Rumex obtusifolius-type pollen in the preimpact sediments from Pico probably indicates that $R$. azoricus has gone extinct from that island, but could indicate that either Rumex obtusifolius or $R$. crispus is native. Pericallis-type probably suggests that a species of Solidago is native, but could indicate 
that Pericallis malvifolia went extinct on Flores. Myriophyllum alterniflorum pollen could indicate that plant's extinction on Pico.

\section{What was the scale of human impact?}

Some idea of the scale of human impact, in ecological terms, can be gauged from the ordination results (Fig. 7), as the axes are scaled to represent turnover (Gauch, 1982).

Consistent with the islands' colonization histories and distribution of remnant vegetation, human impact on the westernmost island of Flores seems to have been somewhat less than on Pico, which is part of the more populous central group of the archipelago. The two Pico sites record human impact somewhat differently as one would expect of sites with different pollen source-areas (Lawson et al., 2008). Preimpact variability also seems to have been higher at the high-elevation sites on Pico, which therefore may also have been more vulnerable to anthropogenic disturbances than middle-elevation vegetation on Flores, remnants of which grow around Lagoa Rasa. The effect of major volcanic eruptions on palaeovegetation succession around the three study sites was significant, as indicated by the earliest pollen assemblage zone in each record (Figs 3-5). In the Lagoa do Caveiro record, this zone encompasses samples from before and after the series of major eruptions around 5150-5200 cal. yr BP. Hence there is no statistical difference between the pre- and post-eruption pollen assemblages until the successional change around $4500 \mathrm{cal}$. yr BP. The most significant change in the pollen records is associated with human colonization, which, in contrast to the recorded volcanic eruptions, introduced new species, caused local extinctions and resulted in long-term changes in vegetation composition. Although larger eruptions in the distant past probably had a catastrophic ecological impact, human colonization seems to have had the most significant impact on the highland vegetation of Flores and 
510 Pico during the period encompassed by the three palaeoecological records considered

511 here.

While it is difficult to directly compare the scale of human impact on the

513 Azorean vegetation with that of other islands, Table 4 provides a few details on some

514 previous pollen-based studies of Atlantic oceanic islands before and after human

515 colonization. The list is not intended to be complete, but nevertheless a striking

516 similarity can be seen in the taxa that increased following human colonization and that

517 many of the major declines were of Juniperus. The palaeoecological signal of human

518 colonization of islands globally is generally rapid and widespread, accompanied by

519 forest decline, loss of 'keystone' arboreal species, proliferation of grasses and fire-

520 tolerant species, appearance of cultivated and ruderal plants, evidence for fire and

521 grazing, and changes to soils and effective moisture availability (Table 4; Flenley et al.,

522 1991; Kirch, 1996; McGlone \& Wilmshurst, 1999; Mann et al., 2008; McWethy et al.,

523 2009; Prebble \& Wilmshurst, 2009). This footprint of island colonization is vividly

524 expressed in the vegetation history of the Azores, providing further indication that it

525 may act as a template for human impacts on terrestrial ecosystems in general.

526 Island vegetation in equatorial regions appears to be more susceptible to plant

527 extinctions and invasions than in higher latitudes, a pattern first alluded to by Hooker

528 (1867; see also Sadler, 1999). Our palaeoecological data from the Azores show that the

529 level of human impact on the vegetation, at least in the highlands, falls somewhere

530 between the drastic modifications evidenced on Tenerife, for example, and the subtle

531 changes recorded on the Faroe Islands (Lawson et al., 2008; de Nascimento et al.,

532 2010). More palaeoecological data from different elevations, islands and latitudes are

533 required to better understand this pattern of susceptibility to human impact, which is of 
534

535

536

\section{CONCLUSIONS}

538

539

540

541

542 extinction.

obvious value in developing ecological theory and identifying species most at risk of

On the Azores, the local impact of major (or localized) volcanic eruptions is detectable palaeoecologically as a 500- to 1000 -year succession from open pioneer communities to greater forest cover. Human impact, on the other hand, took the form of a sudden shift (often over $<100$ years) to open vegetation, which was then maintained over centuries through burning, grazing and edaphic changes. Even so, some differences in the composition of highland vegetation on Flores and Pico persisted after colonization. Human impact on endemic species was generally negative and, in some cases, catastrophic. Some taxa, such as Morella faya, appear to have increased following colonization, while Juniperus brevifolia communities apparently collapsed and at least two species went extinct on Pico. Over the longer term, pollen of Azorean endemic plants were more prevalent immediately following volcanic eruptions, hinting at a prominent role of certain endemic species within primary succession on skeletal soils. The scale of human impact, at least in terms of its palaeoecological effects, was greater than 'natural' impacts such as volcanic eruptions, climatic changes and landslides during recent millennia. Pre-impact palaeoclimatic variations detected using geochemical proxies (Björck et al., 2006) were not clearly reflected as changes in past forest composition or structure, perhaps because of the intensely maritime climate of the archipelago. This observation supports the conclusion that the late Quaternary climate of the Azores was relatively stable in comparison to archipelagos such as the Canary Islands (Ávila et al., 2008; Carine \& Schaefer, 2010). 
Azores shows the extent to which our picture of the pristine, pre-colonization

cannot provide all the missing pieces, it can broaden understanding of the island

ecosystems that preceded major human interventions, helping to elaborate

biogeographical theory and inform conservation efforts.

564

\section{ACKNOWLEDGEMENTS}

We thank Herb Wright (Minnesota), Ole Bennike (Copenhagen), Bernd Kromer

(Heidelberg), Per Möller (Lund) and the Direcção Regional do Ambiente for assisting in the coring campaigns. We gratefully acknowledge Mónica Moura (Açores), Katy Jones (Natural History Museum, London), José Rosa Pinto, João Araújo and Sandra Gomes (Algarve), Maurice Reille and the Geneva Herbarium for pollen reference material and thank Tomasz Boski and Ana Gomes (Algarve) for support in the writing of this paper. We express our particular gratitude to Hanno Schaefer (Harvard), an anonymous referee and our editors, whose insightful comments contributed substantially to improving the manuscript. Pollen data will be made available within the European Pollen Database.

\section{REFERENCES}

577 Ávila, S.P.A., Madeira, P., Mendes, N., Rebelo, A., Medeiros, A., Gomes, C., García- 
581

582

583

584

585

586

587

588

589

590

591

592

593

594

595

596

597

598

599

600

601

602

603

604

Azevedo, J.M.M. \& Ferreira, M.R.P. (1998) Condições da ocorrência e funções hidrogeológicas das lagoas em pequenas ilhas vulcânicas: o exemplo da ilha das Flores - Açores. $4^{\circ}$ Congresso da Água, Lisbon, 23-27 March 1998.

Azevedo, J.M.M. \& Ferreira, M.R.P. (2006) The volcanotectonic evolution of Flores Island, Azores (Portugal). Journal of Volcanology and Geothermal Research, 156, 90-102.

Bennett, K.D. (2008) Psimpoll 4.26. Department of Earth Sciences, Uppsala University, Uppsala.

Berry, R.J. (1992) The significance of island biotas. Biological Journal of the Linnean Society, 46, 3-12.

Björck, S., Rittenour, T., Rosén, P., França, Z., Möller, P., Snowball, I., Wastegård, S., Bennike, O. \& Kromer, B. (2006) A Holocene lacustrine record in the central North Atlantic: proxies for volcanic activity, short-term NAO mode variability, and long-term precipitation changes. Quaternary Science Reviews, 25, 9-32.

Carine, M.A. \& Schaefer, H. (2010) The Azores diversity enigma: why are there so few Azorean endemic flowering plants and why are they so widespread? Journal of Biogeography, 37, 77-89.

CLIMAAT Project (2007) Clima e meteorología dos arquipélagos atlânticos (Climate and meteorology of the Atlantic archipelagos). Universidade dos Açores, Angra de Heroismo. URL: http://www.climaat.angra.uac.pt/.

Collins, A. \& Bush, M.B. (2011) An analysis of modern pollen representation and climatic conditions on the Galápagos Islands. The Holocene, 21, 237-250.

Connor, S.E. (2009) Human impact - the last nail in the coffin for ancient plants? Journal of Biogeography, 36, 485-486. 
605

606

607

608

609

610

611

612

613

614

615

616

617

618

619

620

621

622

623

624

625

626

627

628

629

Costa, C. (1950) Arvoredos dos Açores: algumas achegas para a sua história. Comissão Reguladora dos Cereais do Arquipélago dos Açores, 11, 45-60.

Dias, E. (1996) Vegetação natural dos Açores: ecologia e sintaxonomia das florestas naturais. Unpublished PhD Thesis, Universidade dos Açores, Angra de Heroismo.

Elias R. B. \& Dias E. (2004) Primary succession on lava domes on Terceira (Azores). Journal of Vegetation Science, 15, 331-338.

Fernández-Palacios, J.M., de Nascimento, L., Otto, R., Delgado, J.D., García-del-Rey, E., Arévalo, J.R. \& Whittaker, R.J. (2011) A reconstruction of PalaeoMacaronesia, with particular reference to the long-term biogeography of the Atlantic island laurel forests. Journal of Biogeography, 38, 226-246.

Ferreira, A.B. (2005) Geodinâmica e perigosidade natural nas ilhas dos Açores. Finisterra, 40, 103-120.

Flenley, J.R., King, A.S.M., Jackson, J., Chew, C., Teller, J.T. \& Prentice, M.E. (1991) The Late Quaternary vegetational and climatic history of Easter Island. Journal of Quaternary Science, 6, 85-115.

Forjaz, V.H, Monjardino, J.L. \& Fernandes, N. (1970) Contribuição para o estudo das jazidas fossilíferas das ilhas do Faial, Pico, S. Jorge e Terceira (Açores). Comunicações dos Serviços Geológicos de Portugal, 54, 27-37.

Fries, M. (1968) Organic sediment and radiocarbon dates from crater lakes on the Azores. Geologiska Föreningens i Stockholm Förhandlingar, 90, 360-368.

Gauch, H.G. (1982) Multivariate analysis in community ecology. Cambridge University Press, Cambridge.

van Geel, B. \& Aptroot, A. (2006) Fossil ascomycetes in Quaternary deposits. Nova Hedwigia, 82, 313-329. 
630

631

632

633

634

635

636

637

638

639

640

641

642

643

644

645

646

647

648

649

650

651

652

653

Grimm, E.C. (2004) TILIA and TGView software, version 2.0.2. Illinois State Museum, Research and Collections Center, Springfield, IL.

Hannon, G.E. \& Bradshaw, R.H.W. (2000) Impacts and timing of the first human settlement on vegetation of the Faroe Islands. Quaternary Research, 54, 404413.

Head, L. (2008) Is the concept of human impacts past its use-by date? The Holocene, 18, 373-377.

Hooker, J.D. (1867) Insular floras. Gardener's Chronicle and Agricultural Gazette, January, 6-7, 27, 50-51, 75-76.

Johnson, D.S. (1994) Phantom islands of the Atlantic: the legends of seven lands that never were. Souvenir Press, London.

Kirch, P.V. (1996) Late Holocene human-induced modifications to a central Polynesian island ecosystem. Proceedings of the National Academy of Sciences, USA, 93, $5296-5300$.

van der Knaap, W.O. (2009) Estimating pollen diversity from pollen accumulation rates: a method to assess taxonomic richness in the landscape. The Holocene, 19, 159-163.

Kueffer, C., Daehler, C.C., Torres-Santana, C.W., Lavergne, C., Meyer, J.-Y., Otto, R. \& Silva, L. (2010) A global comparison of plant invasions on oceanic islands. Perspectives in Plant Ecology, Evolution \& Systematics, 12, 145-161.

Lawson, I.T., Gathorne-Hardy, F.J., Church, M.J., Newton, A.J., Edwards, K.J., Dugmore, A.J. \& Einarsson, Á. (2007) Environmental impacts of the Norse settlement: palaeoenvironmental data from Mývatnssveit, northern Iceland. Boreas, 36, 1-19. 
654

655

656

657

658

659

660

661

662

663

664

665

666

667

668

669

670

671

672

673

674

675

676

677

678

Lawson, I.T., Edwards, K.J., Church, M.J., Newton, A.J., Cook, G.T., Gathorne-Hardy, F.J. \& Dugmore, A.J. (2008) Human impact on an island ecosystem: pollen data from Sandoy, Faroe Islands. Journal of Biogeography, 35, 1130-1152.

van Leeuwen, J.F.N., Schaefer, H., van der Knaap, W.O., Rittenour, T., Björck, S. \& Ammann, B. (2005) Native or introduced? Fossil pollen and spores may say - an example from the Azores Islands. Neobiota, 6, 27-34.

van Leeuwen, J.F.N., Froyd, C.A., van der Knaap, W.O., Coffey, E.E., Tye, A. \& Willis, K.J. (2008) Fossil pollen as a guide to conservation in the Galápagos. Science, 322, 1206.

Ljung, K. \& Björck, S. (2011) A pollen record of the last 450 years from a lowland peat bog on Tristan da Cunha, South Atlantic, implying early anthropogenic influence. Journal of Quaternary Science, 26, 688-693.

Mann, D., Edwards, J., Chase, J, Beck, W., Reanier, R., Mass, M., Finney, B. \& Loret, J. (2008) Drought, vegetation change, and human history on Rapa Nui (Isla de Pascua, Easter Island). Quaternary Research, 69, 16-28.

McCune, B. \& Mefford, M. J. (1999) PC-ORD: multivariate analysis of ecological data. MjM Software Design, Gleneden Beach, OR.

McGlone, M.S. \& Wilmshurst, J.M. (1999) Dating intitial Maori environmental impact in New Zealand. Quaternary International, 59, 5-16.

McWethy, D.B., Whitlock, C., Wilmshurst, J.M., McGlone, M.S. \& Li, X. (2009) Rapid deforestation of South Island, New Zealand, by early Polynesian fires. The Holocene, 19, 883-897.

Moore, P.D. (1975) Origin of blanket mires. Nature, 256, 267-269.

Moore, P.D., Webb, J.A. \& Collinson, M.E. (1991) Pollen analysis. Blackwell Science Publishers, Oxford. 
679

680

681

682

683

684

685

686

687

688

689

690

691

692

693

694

695

696

697

698

699

700

701

702

703

Morriseau, M. \& Traineau, H. (1985) Mise en évidence d'une activité hydromagmatique Holocène sur l'Île de Flores (Açores). Comptes Rendus de l'Académie des Sciences Paris, 301, 1309-1314.

Mueller-Dombois, D. (1975) Some aspects of island ecosystem analysis. Tropical ecological systems: trends in aquatic and terrestrial research (ed. by F.B. Golley and E. Medina), pp. 353-366. Springer-Verlag, New York.

de Nascimento, L., Willis, K.J., Fernández-Palacios, J.M., Criado, C. \& Whittaker, R.J. (2009) The long-term ecology of the lost forests of La Laguna, Tenerife (Canary Islands). Journal of Biogeography, 36, 499-514.

Odgaard, B.V. (1999) Fossil pollen as a record of past biodiversity. Journal of Biogeography, 26, 7-17.

Prebble, M. \& Wilmshurst, J.M. (2009) Detecting the initial impact of humans and introduced species on island environments in Remote Oceania using palaeoecology. Biological Invasions, 11, 1529-1556.

Pugin, A. \& Girardclos, S. (1998) Shallow seismic reflection on two Azores volcanic lakes. Unpublished report, University of Geneva, Department of Geology and Paleontology, Geneva.

Reille, M. (1992, 1995 \& 1998) Pollen et spores d'Europe et d'Afrique du Nord (3 vols). Laboratoire de Botanique historique et Palynologie, Marseille.

Reimer, P.J. \& Reimer, R. (not dated) CALIBomb radiocarbon calibration. Queen’s University Belfast, Belfast. URL: http://calib.qub.ac.uk/CALIBomb/ (accessed 15/8/2011).

Rueger, B.F. \& von Wallmenich, T.N. (1996) Human impact on the forests of Bermuda: the decline of endemic cedar and palmetto since 1609, recorded in the Holocene pollen record of Devonshire Marsh. Journal of Paleolimnology, 16, 59-66. 
704

705

706

707

708

709

710

711

712

713

714

715

716

717

718

719

720

721

722

723

724

725

726

727

Sadler, J.P. (1999) Biodiversity on oceanic islands: a palaeoecological assessment. Journal of Biogeography, 26, 75-87.

Schaefer, H. (2003) Chorology and diversity of the Azorean flora. Dissertationes Botanicae, Vol. 374. J. Cramer, Stuttgart.

Schaefer, H. (2005) Flora of the Azores: a field guide, $2^{\text {nd }}$ edn. Margraf Publishers, Weikersheim.

Schaefer, H., Moura, M., Belo Maciel, M.G., Silva, L., Rumsey, F.J. \& Carine, M.A. (2011) The Linnean shortfall in oceanic island biogeography: a case study in the Azores. Journal of Biogeography, 38, 1345-1355.

Schirone, B., Ferreira, R.C., Vessela, F., Schirone, A., Piredda, R. \& Simeone, M.C. (2010) Taxus baccata in the Azores: a relict form at risk of imminent extinction. Biodiversity and Conservation, 19, 1547-1565.

Silva, L., Moura, M., Schaefer, H., Rumsey, F. \& Dias, E.F. (2010) Vascular plants (Tracheobionta). A list of the terrestrial and marine biota from the Azores (ed. by P.A.V. Borges, A. Costa, R. Cunha, R. Gabriel, V. Gonçalves, A.F. Martins, I. Melo, M. Parente, P. Raposeiro, P. Rodrigues, R.S. Santos, L. Silva, P. Vieira and V. Vieira), pp. 117-146. Princípia, Cascais.

Sjögren, E. (1973) Conservation of natural plant communities on Madeira and in the Azores. Monographiae Biologicae Canarienses, 4, 148-153.

Stuiver, M. \& Reimer, P.J. (1993) Extended ${ }^{14} \mathrm{C}$ database and revised CALIB radiocarbon calibration program. Radiocarbon, 35, 215-230.

Tutin, T.G. (1953) Vegetation of the Azores. Journal of Ecology, 41, 53-61.

Webb, D.A. (1985) What are the criteria for presuming native status? Watsonia, 15, 231-236. 
728

729

730

731

732

733

734

735

736

737

738

739

740

741

(1)

Whittaker, R.J., Triantis, K.A. \& Ladle, R.J. (2008) A general dynamic theory of oceanic island biogeography. Journal of Biogeography, 35, 977-994.

Williamson, M. (1984) Sir Joseph Hooker’s lecture on insular floras. Biological Journal of the Linnean Society, 22, 55-77.

Wright, H.E. (1967) A square-rod piston sampler for lake sediments. Journal of Sedimentary Petrology, 37, 975-976.

Zbyszewski, G., Ferreira, C.R., Ferreira, O.V. \& Assunção, C.T. (1963) Carta

Geológica de Portugal 1/50000: notícia explicativa da folha 'B' da Ilha do Pico (Açores). Serviços Geológicos de Portugal, Lisbon.

Zbyszewski, G., Medeiros, A.C., Ferreira, O.V. \& Assunção, C.T. (1968) Carta Geológica de Portugal 1/25000: notícia explicativa da folha da Ilha das Flores (Açores). Serviços Geológicos de Portugal, Lisbon. 


\section{SUPPORTING INFORMATION}

743 Additional Supporting Information may be found in the online version of this article:

745 Appendix S1 Complete pollen diagrams from Lagoa Rasa, Lagoa do Caveiro and Pico 746 Bog.

747

748 As a service to our authors and readers, this journal provides supporting information 749 supplied by the authors. Such materials are peer-reviewed and may be re-organized for 750 online delivery, but are not copy-edited or typeset. Technical support issues arising 751 from supporting information (other than missing files) should be addressed to the 752 authors. 
756 Simon Connor is a researcher in environmental dynamics at the University of the

757 Algarve. His research interests include human-environment interactions and the 758 biogeography of Tertiary relict species.

759

760 Author contributions: S.E.C., J.F.N.L., W.O.K. and B.A. developed the ideas; J.F.N.L.

761 and T.M.R. analysed the pollen data; B.A. and S.B. initiated the project; S.E.C. and

762 W.O.K. made the numerical analyses; and S.E.C. wrote the paper with the help of all 763 co-authors.

764

765 Editor: José María Fernández-Palacios 


\section{TABLES}

769 Table 1 Site details for the three coring locations on the Azores.

\begin{tabular}{|c|c|c|c|c|c|}
\hline $\begin{array}{l}\text { Site name, } \\
\text { island }\end{array}$ & $\begin{array}{l}\text { Elevation } \\
\text { a.s.l. }\end{array}$ & Coordinates & $\begin{array}{l}\text { Dimensions (max. } \\
\text { water depth) }\end{array}$ & Site description & Surrounding vegetation \\
\hline $\begin{array}{l}\text { Lagoa Rasa, } \\
\text { Flores }\end{array}$ & $530 \mathrm{~m}$ & $\begin{array}{l}39^{\circ} 24.50^{\prime} \mathrm{N}, \\
31^{\circ} 13.50^{\prime} \mathrm{W}\end{array}$ & $325 \times 425 \mathrm{~m}(16 \mathrm{~m})$ & $\begin{array}{l}\text { Crater lake formed } \\
\text { by Strombolian } \\
\text { eruption }\end{array}$ & $\begin{array}{l}\text { Moorland with scattered } \\
\text { Juniperus brevifolia, Erica } \\
\text { azorica and Calluna } \\
\text { vulgaris; Sphagnum } \\
\text { around lake shores }\end{array}$ \\
\hline $\begin{array}{l}\text { Lagoa do } \\
\text { Caveiro, } \\
\text { Pico }\end{array}$ & $903 \mathrm{~m}$ & $\begin{array}{l}38^{\circ} 26.10^{\prime} \mathrm{N}, \\
28^{\circ} 11.79^{\prime} \mathrm{W}\end{array}$ & $30 \times 40 \mathrm{~m}(3.5 \mathrm{~m})$ & $\begin{array}{l}\text { Crater lake with } \\
\text { Potamogeton } \\
\text { polygonifolius }\end{array}$ & $\begin{array}{l}\text { Grassland of Festuca } \\
\text { francoi; scattered remnants } \\
\text { of Juniperus forest and } \\
\text { laurisilva }\end{array}$ \\
\hline $\begin{array}{l}\text { Pico Bog, } \\
\text { Pico }\end{array}$ & $873 \mathrm{~m}$ & $\begin{array}{l}38^{\circ} 26.16^{\prime} \mathrm{N}, \\
28^{\circ} 10.30^{\prime} \mathrm{W}\end{array}$ & $20 \times 25 \mathrm{~m}(1.5 \mathrm{~m})$ & Sphagnum bog & $\begin{array}{l}\text { Grassland of Festuca } \\
\text { francoi; scattered remnants } \\
\text { of Juniperus forest and } \\
\text { laurisilva }\end{array}$ \\
\hline
\end{tabular}


Table 2 Azorean pollen taxa that could be confidently classified as having endemic, native or introduced status and their occurrence (x) in the three records, both before (B) and after (A) significant human impact. Status based on Silva et al. (2010), except where the pollen evidence demonstrates native status (taxa in boldface). The † symbol denotes taxa now extinct on Pico. The endemic category also includes Macaronesian endemics. Single pollen-grain occurrences are indicated by a dot $(\bullet)$ and 49 taxa that could not be categorized for pollentaxonomic reasons are omitted (see Appendix S1).

\begin{tabular}{|c|c|c|c|c|c|c|c|}
\hline \multirow[t]{2}{*}{ Status } & \multirow[t]{2}{*}{ Taxon } & \multicolumn{2}{|c|}{ Rasa } & \multicolumn{2}{|c|}{ Caveiro } & \multicolumn{2}{|c|}{ Pico } \\
\hline & & A & B & A & $\mathrm{B}$ & A & $\mathrm{B}$ \\
\hline \multirow[t]{19}{*}{ Endemic } & Angelica lignescens & $\mathrm{X}$ & $\mathrm{X}$ & $\mathrm{X}$ & $\mathrm{X}$ & $X$ & $\mathrm{X}$ \\
\hline & Arceuthobium azoricum & & & $\mathrm{x}$ & $\mathrm{x}$ & $\mathrm{x}$ & $\mathrm{x}$ \\
\hline & Bellis-type & $\mathrm{x}$ & $\mathrm{x}$ & $\mathrm{x}$ & $\mathrm{x}$ & $\mathrm{x}$ & $\mathrm{x}$ \\
\hline & Chaerophyllum azoricum & $\mathrm{x}$ & & $\mathrm{x}$ & $\mathrm{x}$ & $\bullet$ & $\mathrm{x}$ \\
\hline & Daucus carota ssp. azorica & • & & $\mathrm{x}$ & $\mathrm{x}$ & & • \\
\hline & Diphasiastrum madeirense & $\mathrm{x}$ & $\mathrm{x}$ & $\mathrm{x}$ & $\mathrm{x}$ & $\mathrm{x}$ & $\mathrm{x}$ \\
\hline & Erica azorica & $\mathrm{x}$ & $\mathrm{x}$ & & & & \\
\hline & Ericaceae & $\mathrm{x}$ & $\mathrm{x}$ & $\mathrm{x}$ & $\mathrm{x}$ & $\mathrm{x}$ & $\mathrm{x}$ \\
\hline & Euphrasia & - & $\mathrm{x}$ & - & $\mathrm{x}$ & & \\
\hline & Frangula azorica & $\mathrm{x}$ & $\mathrm{x}$ & $\mathrm{x}$ & $\mathrm{x}$ & • & • \\
\hline & Hedera azorica & • & $\mathrm{x}$ & $\mathrm{x}$ & $\mathrm{X}$ & & $\mathrm{x}$ \\
\hline & Huperzia dentata & $\mathrm{x}$ & $\mathrm{x}$ & $\mathrm{x}$ & $\mathrm{x}$ & $\mathrm{x}$ & $\mathrm{x}$ \\
\hline & Huperzia suberecta & & & $\mathrm{x}$ & $\mathrm{x}$ & $\bullet$ & $\mathrm{x}$ \\
\hline & Ilex perado ssp. azorica & $\mathrm{x}$ & $\mathrm{x}$ & $\mathrm{x}$ & $\mathrm{x}$ & $\mathrm{x}$ & $\mathrm{x}$ \\
\hline & Juniperus brevifolia & $\mathrm{x}$ & $\mathrm{x}$ & $\mathrm{x}$ & $\mathrm{x}$ & $\mathrm{x}$ & $\mathrm{x}$ \\
\hline & Lysimachia azorica & $\mathrm{x}$ & $\mathrm{x}$ & $\mathrm{x}$ & $\mathrm{x}$ & $\mathrm{x}$ & $\mathrm{x}$ \\
\hline & Picconia azorica & $\mathrm{x}$ & $\mathrm{x}$ & $\mathrm{x}$ & $\mathrm{x}$ & $\mathrm{x}$ & $\mathrm{x}$ \\
\hline & Polypodium azoricum & $\mathrm{x}$ & $\mathrm{x}$ & $\mathrm{x}$ & $\mathrm{x}$ & $\mathrm{x}$ & $\mathrm{x}$ \\
\hline & Prunus azorica & & & $\mathrm{x}$ & $\mathrm{x}$ & $\mathrm{X}$ & • \\
\hline
\end{tabular}


Vaccinium cylindraceum

Viburnum treleasei

Apium

Athyrium filix-femina

Blechnum

Botrychium lunaria

Calluna vulgaris

cf. Umbilicus

Cheilanthes-type

Culcita macrocarpa

Daphne laureola

Hydrocotyle vulgaris

Hymenophyllum tunbrigense-type

Illecebrum verticillatum

Lycopodiella inundata

Lythrum portula

Morella faya

Myrsine africana

Ophioglossum azoricum $\dagger$

Ophioglossum lusitanicum†

Osmunda regalis

\section{Persicaria}

Plantago coronopus

Potentilla-type

Pteridium aquilinum

Pteris incompleta

Selaginella kraussiana

Trichomanes speciosum

Introduced Castanea sativa

Cerealia

Cryptomeria japonica

Hydrangea macrophylla

\begin{tabular}{|c|c|c|c|c|c|}
\hline X & $\mathrm{X}$ & $\mathrm{x}$ & $x$ & $X$ & \\
\hline X & $\mathrm{X}$ & & & & \\
\hline & & • & $\mathrm{x}$ & & \\
\hline & & & & & \\
\hline $\mathrm{X}$ & & & & & \\
\hline & & $\mathrm{x}$ & $x$ & & \\
\hline $\mathrm{X}$ & $\mathrm{X}$ & $\mathrm{x}$ & $\mathrm{X}$ & $\mathrm{X}$ & \\
\hline $\mathrm{X}$ & $\mathrm{x}$ & & & & \\
\hline $\mathrm{X}$ & $\mathrm{X}$ & $\mathrm{x}$ & $\mathrm{x}$ & • & \\
\hline $\mathrm{X}$ & $\mathrm{X}$ & $\mathrm{x}$ & $\mathrm{x}$ & $\mathrm{X}$ & \\
\hline & & $\mathrm{x}$ & $\mathrm{X}$ & & \\
\hline & & $\mathrm{x}$ & & $\mathrm{X}$ & \\
\hline $\mathrm{X}$ & $\mathrm{x}$ & $\mathrm{x}$ & $\mathrm{x}$ & & \\
\hline & $\mathrm{X}$ & $\mathrm{x}$ & $\mathrm{x}$ & $\mathrm{X}$ & \\
\hline & $\mathrm{x}$ & & $\mathrm{x}$ & & \\
\hline & & $\mathrm{x}$ & $\mathrm{x}$ & & \\
\hline $\mathrm{X}$ & $\mathrm{x}$ & $\mathrm{x}$ & $\mathrm{x}$ & $\mathrm{X}$ & \\
\hline $\mathrm{x}$ & $\mathrm{X}$ & $\mathrm{x}$ & $\mathrm{x}$ & $\mathrm{X}$ & \\
\hline $\mathrm{X}$ & $\mathrm{X}$ & $\mathrm{x}$ & $\mathrm{x}$ & & \\
\hline $\mathrm{X}$ & $\mathrm{x}$ & $\mathrm{x}$ & $\mathrm{x}$ & & \\
\hline $\mathrm{X}$ & $\mathrm{X}$ & $\mathrm{x}$ & $\mathrm{x}$ & $\mathrm{X}$ & \\
\hline & $\mathrm{X}$ & & $\mathrm{x}$ & & \\
\hline & & $\mathrm{x}$ & & • & \\
\hline $\mathrm{X}$ & $\mathrm{X}$ & $\mathrm{x}$ & $\mathrm{x}$ & $\mathrm{X}$ & \\
\hline $\mathrm{X}$ & $\mathrm{x}$ & $\mathrm{x}$ & $\mathrm{X}$ & $\mathrm{X}$ & \\
\hline $\mathrm{X}$ & $\mathrm{X}$ & $\mathrm{x}$ & $\mathrm{x}$ & $\mathrm{X}$ & \\
\hline $\mathrm{X}$ & $\mathrm{x}$ & $\mathrm{x}$ & $\mathrm{x}$ & $\mathrm{X}$ & \\
\hline $\mathrm{X}$ & $\mathrm{x}$ & $\mathrm{x}$ & $\mathrm{X}$ & $\mathrm{X}$ & \\
\hline & • & $\mathrm{x}$ & & & 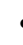 \\
\hline
\end{tabular}




\begin{tabular}{|c|c|c|c|c|c|c|}
\hline Ligustrum & $\mathrm{x}$ & & $\mathrm{x}$ & & & \\
\hline Pinus & $\mathrm{x}$ & • & $\mathrm{x}$ & - & & \\
\hline Plantago lanceolata & $\mathrm{x}$ & • & $\mathrm{x}$ & • & $\mathrm{x}$ & \\
\hline Plantago major & & & $\mathrm{x}$ & & & \\
\hline Prunella vulgaris & & & & & & $\mathrm{x}$ \\
\hline Secale & $\mathrm{x}$ & & & & & \\
\hline Ulex-type & • & & & & & \\
\hline Verbena officinalis & $\bullet$ & & & & & \\
\hline Vitis & & & $\mathrm{x}$ & & - & \\
\hline Zea mays & - & & & & & \\
\hline
\end{tabular}


Table 3 Radiocarbon ages from dated gyttja (Lagoa Rasa) and peat (Pico Bog) sediments, with calendar ages (calibrated with 2-sigma

780 probability). The first age post-dates $\mathrm{AD} 1950$ and is therefore expressed as percentage modern carbon (pMC).

\begin{tabular}{|c|c|c|c|}
\hline Site and depth & $\begin{array}{l}{ }^{14} \mathrm{C} \text { age (yr BP) and } \\
\text { error }\end{array}$ & $\begin{array}{l}\text { Calendar age (cal. } \\
\text { yr BP) }\end{array}$ & Lab code \\
\hline Rasa $124 \mathrm{~cm}$ & $109.8 \pm 0.3 \mathrm{pMC}$ & -5 or $-45--50$ & Poz-2095 \\
\hline Rasa $168 \mathrm{~cm}$ & $220 \pm 30$ & $-1-308$ & Poz-2210 \\
\hline Rasa $176 \mathrm{~cm}$ & $335 \pm 30$ & $309-477$ & Poz-9890 \\
\hline Rasa $188 \mathrm{~cm}$ & $505 \pm 35$ & $501-625$ & Poz-2098 \\
\hline Rasa $200 \mathrm{~cm}$ & $580 \pm 30$ & $553-649$ & Poz-11260 \\
\hline Rasa $210 \mathrm{~cm}$ & $695 \pm 30$ & $563-686$ & Poz-11261 \\
\hline Rasa 226 cm & $705 \pm 35$ & $561-699$ & Poz-2099 \\
\hline Rasa 245 cm & $895 \pm 35$ & 735-911 & Poz-2100 \\
\hline Rasa $280 \mathrm{~cm}$ & $1290 \pm 30$ & 1175-1287 & Poz-9926 \\
\hline Rasa $290 \mathrm{~cm}$ & $1345 \pm 30$ & 1182-1309 & Poz-11263 \\
\hline Rasa 305 cm & $1565 \pm 30$ & 1390-1527 & Poz-11264 \\
\hline Rasa 315 cm & $1710 \pm 35$ & $1541-1702$ & Poz-11467 \\
\hline Rasa $321 \mathrm{~cm}$ & $2105 \pm 30$ & $1996-2149$ & Poz-9927 \\
\hline Rasa 324 cm & $2450 \pm 35$ & $2358-2703$ & Poz-11221 \\
\hline Rasa 328 cm & $2370 \pm 35$ & $2335-2672$ & Poz-1222 \\
\hline Rasa $330 \mathrm{~cm}$ & $2435 \pm 41$ & 2353-2702 & UtC-8340 \\
\hline Pico $152-153 \mathrm{~cm}$ & $240 \pm 50$ & $-11-470$ & LuS-5872 \\
\hline Pico 232-233 cm & $410 \pm 50$ & $310-530$ & LuS-5870 \\
\hline Pico 262 cm & $570 \pm 50$ & $510-660$ & LuS-6103 \\
\hline Pico 292-293 cm & $750 \pm 50$ & $560-780$ & LuS-5869 \\
\hline Pico 346-347 cm & $860 \pm 100$ & $650-970$ & LuS-5868 \\
\hline Pico $417-418 \mathrm{~cm}$ & $1140 \pm 50$ & $930-1180$ & LuS-5867 \\
\hline Pico 465-466 cm & $1460 \pm 50$ & $1280-1520$ & LuS-5866 \\
\hline Pico 498 cm & $1645 \pm 50$ & $1410-1700$ & LuS-6104 \\
\hline
\end{tabular}




\begin{tabular}{llll} 
Pico 546-548 cm & $1892 \pm 133$ & $1500-2200$ & Hd-21645 \\
Pico 559 cm & $2405 \pm 50$ & $2340-2710$ & LuS-6105 \\
Pico 571-572 cm & $2550 \pm 50$ & $2460-2770$ & LuS-5871 \\
\hline
\end{tabular}


784 Table 4 Comparison of some palynological studies that record the impact of human colonization of oceanic islands of the Atlantic. Sites are

785 listed in north-south order. $\dagger=$ extinction. Further details can be found in the studies themselves.

\begin{tabular}{|c|c|c|c|c|c|c|}
\hline $\begin{array}{l}\text { Site and } \\
\text { reference }\end{array}$ & $\begin{array}{l}\text { Timing } \\
\text { (cal. } \\
\text { BP) }\end{array}$ & $\begin{array}{l}\text { Major pollen } \\
\text { declines }\end{array}$ & $\begin{array}{l}\text { Major pollen } \\
\text { increases }\end{array}$ & $\begin{array}{l}\text { Introduced } \\
\text { pollen taxa }\end{array}$ & Fire and grazing & Soils and moisture \\
\hline $\begin{array}{l}\text { Iceland } \\
\text { (Lawson et al., } \\
\text { 2007) }\end{array}$ & c. 1080 & $\begin{array}{l}\text { Betula } \\
\text { Juniperus }\end{array}$ & $\begin{array}{l}\text { Poaceae } \\
\text { Cyperaceae }\end{array}$ & Hordeum & $\begin{array}{l}\text { Increased charcoal; } \\
\text { grazing inferred }\end{array}$ & $\begin{array}{l}\text { Soil } \\
\text { acidification; } \\
\text { expansion of } \\
\text { Sphagnum }\end{array}$ \\
\hline $\begin{array}{l}\text { Faroe Islands } \\
\text { (Hannon \& } \\
\text { Bradshaw, } \\
\text { 2000) }\end{array}$ & c. 1400 & $\begin{array}{l}\text { Juniperus } \\
\text { Cyperaceae }\end{array}$ & $\begin{array}{l}\text { Poaceae } \\
\text { Cerealia }\end{array}$ & $\begin{array}{l}\text { Recorded in } \\
\text { macrofossils }\end{array}$ & $\begin{array}{l}\text { Charcoal peak; grazing } \\
\text { inferred }\end{array}$ & $\begin{array}{l}\text { Change in } \\
\text { wetland taxa }\end{array}$ \\
\hline $\begin{array}{l}\text { Flores \& Pico, } \\
\text { Azores (this } \\
\text { paper) }\end{array}$ & c. 400 & Juniperus & $\begin{array}{l}\text { Poaceae } \\
\text { Pteridium }\end{array}$ & $\begin{array}{l}\text { Hydrangea } \\
\text { Cryptomeria } \\
\text { Cerealia etc. }\end{array}$ & $\begin{array}{l}\text { Charcoal and Sporor- } \\
\text { miella increase }\end{array}$ & $\begin{array}{l}\text { Expansion } \\
\text { of } \\
\text { Sphagnum }\end{array}$ \\
\hline $\begin{array}{l}\text { Bermuda } \\
\text { (Rueger \& von } \\
\text { Wallmenich, } \\
\text { 1996) }\end{array}$ & c. 350 & $\begin{array}{l}\text { Juniperus } \\
\text { Sabal }\end{array}$ & $\begin{array}{l}\text { Morella } \\
\text { Poaceae } \\
\text { Cyperaceae }\end{array}$ & $\begin{array}{l}\text { Not shown on } \\
\text { pollen diagram }\end{array}$ & Historical records cited & $\begin{array}{l}\text { Transition } \\
\text { from swamp } \\
\text { forest to } \\
\text { marsh }\end{array}$ \\
\hline $\begin{array}{l}\text { Tenerife (de } \\
\text { Nascimento et } \\
\text { al., 2010) }\end{array}$ & c. 2000 & $\begin{array}{l}\text { Quercus } \dagger \\
\text { Carpinus } \dagger\end{array}$ & $\begin{array}{l}\text { Morella } \\
\text { Poaceae } \\
\text { Asteraceae }\end{array}$ & No mention & Charcoal increase & $\begin{array}{l}\text { Lowered } \\
\text { lake level }\end{array}$ \\
\hline $\begin{array}{l}\text { Tristan da } \\
\text { Cunha (Ljung } \\
\text { \& Bjorck, } \\
\text { 2011) }\end{array}$ & c. 300 & $\begin{array}{l}\text { Phylica } \\
\text { arborea }\end{array}$ & $\begin{array}{l}\text { Plantago } \\
\text { Rumex } \\
\text { Cyperaceae }\end{array}$ & $\begin{array}{l}\text { Plantago } \\
\text { lanceolata } \\
\text { Rumex acetosa }\end{array}$ & $\begin{array}{l}\text { Increased charcoal; } \\
\text { grazing inferred }\end{array}$ & $\begin{array}{l}\text { Erosion; } \\
\text { change to } \\
\text { Cyperaceae } \\
\text { dominance }\end{array}$ \\
\hline
\end{tabular}




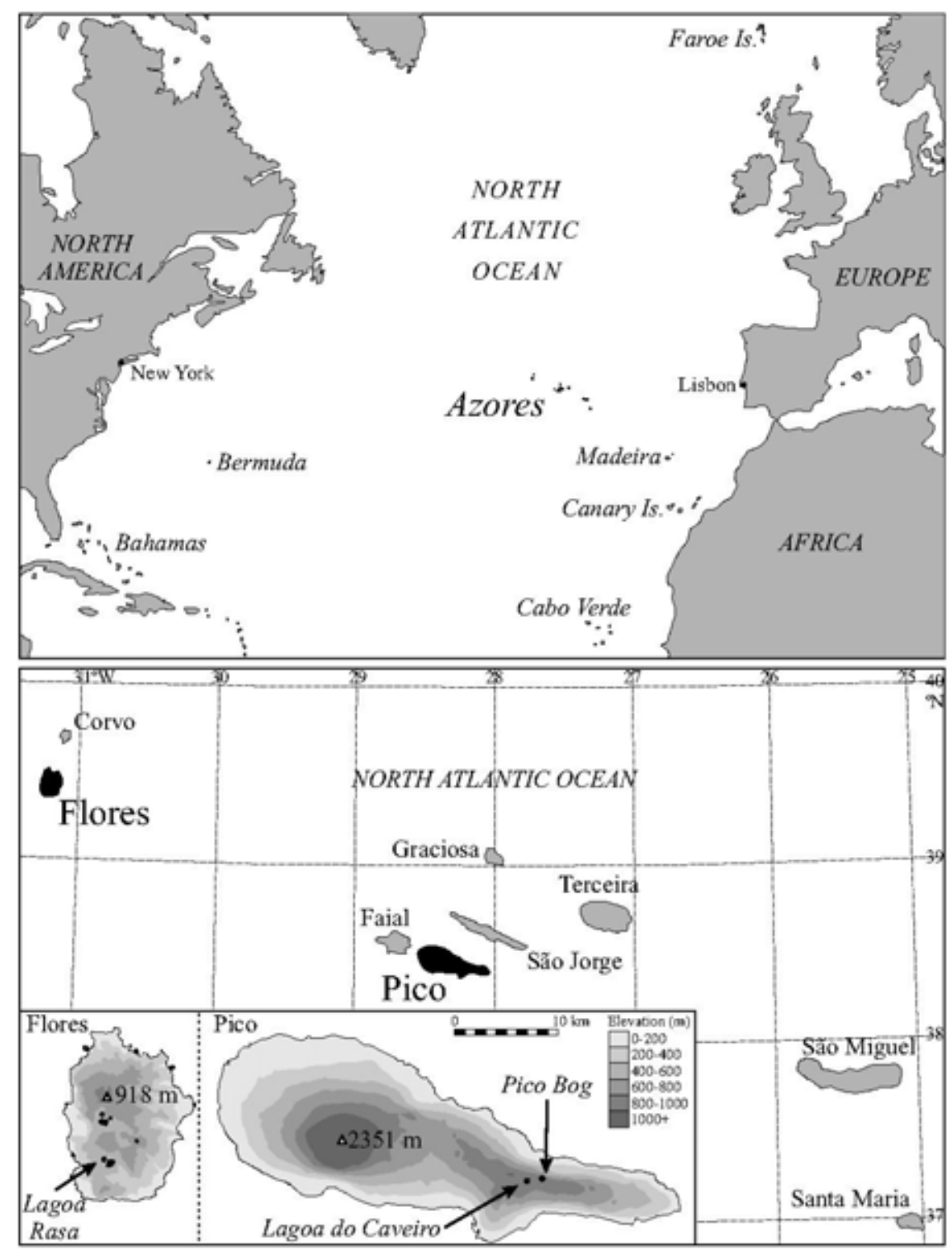

Figure 1 Map of the North Atlantic region, showing the location of the Azores archipelago and other islands (above). Map of the Azores (below) and the study sites (inset). 


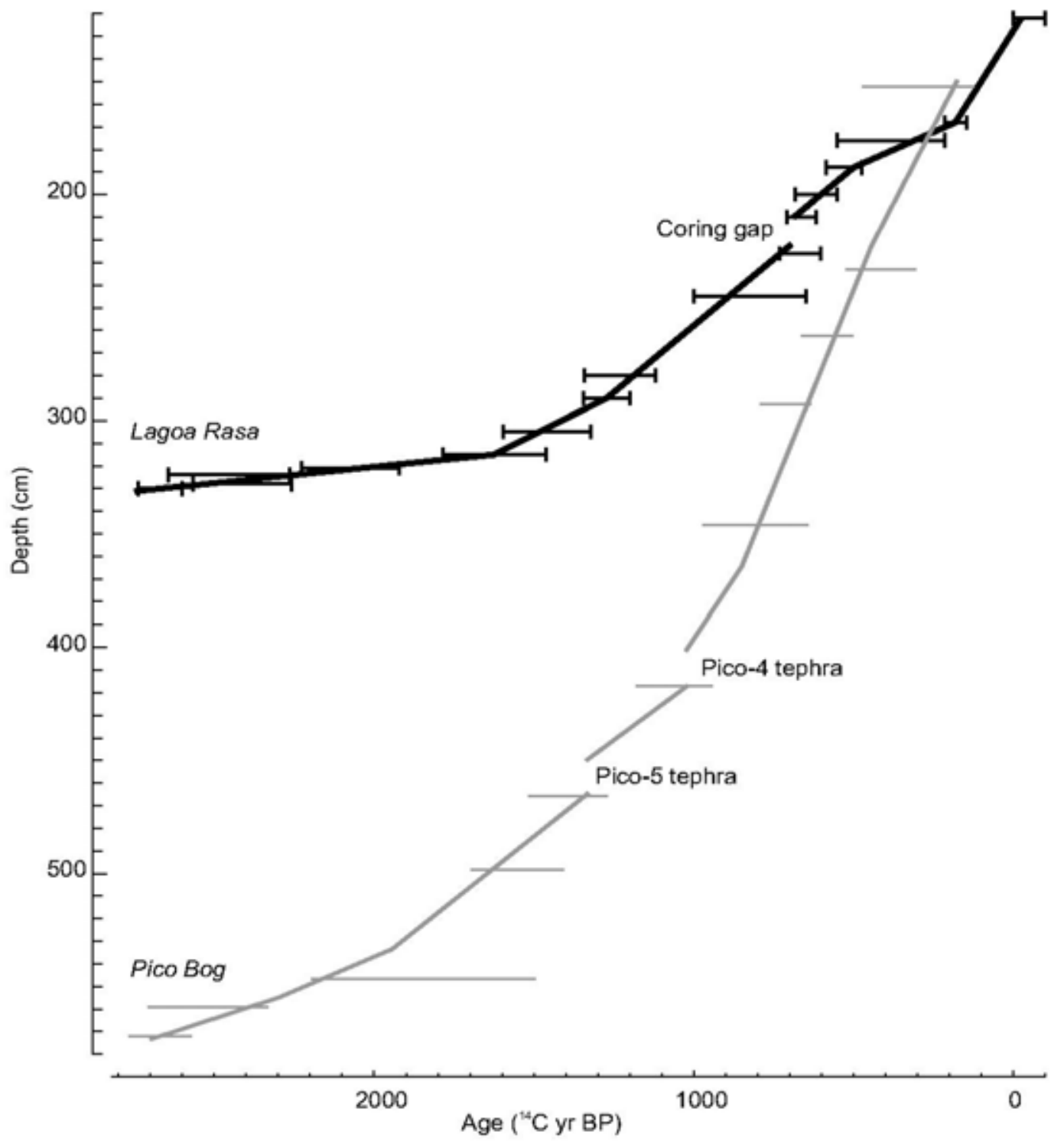

796 Figure 2 Age-depth profiles, for sediment records from Lagoa Rasa on the island of 797 Flores (black line) and Pico Bog on the island of Pico (grey line), based on the radiocarbon ages in Table 3. An age-depth curve for the Lagoa do Caveiro record (Pico Island) appears in Björck et al. (2006).

800 


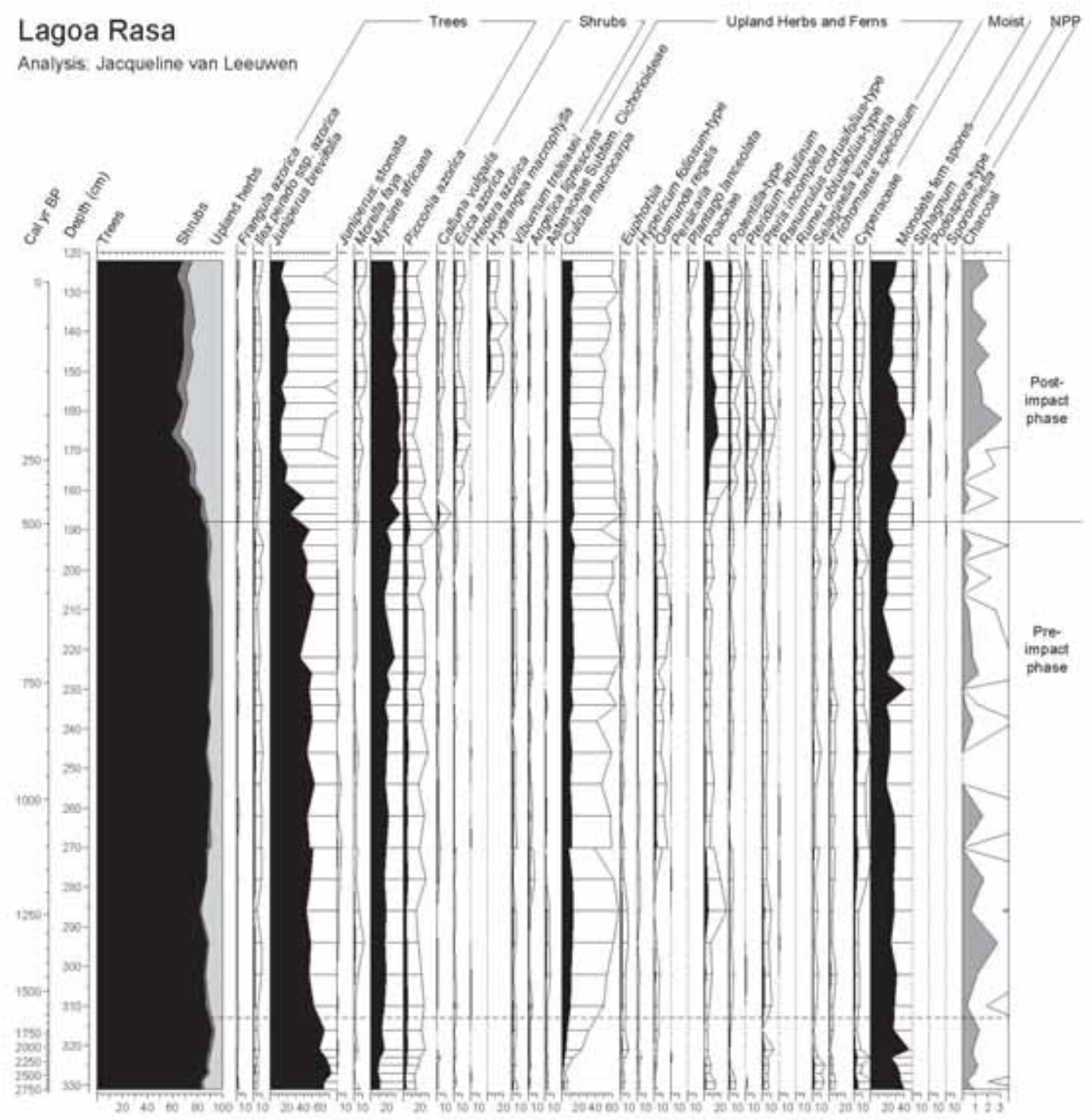

802

Figure 3 Pollen diagram from Lagoa Rasa on the island of Flores, showing (left to right) sample ages, depths, pollen assemblage summary, trees, shrubs, herbs, ferns and aquatic/wetland pollen types. Non-pollen palynomorphs (NPP) and charcoal are shown on the right. Open curves are $5 \times$ exaggerations of the black percentage curves. The solid horizontal line is the zone boundary between pre-impact (below) and post-impact samples (above); dotted lines indicate other significant zone boundaries. See Appendix S1 for the complete pollen diagram. 


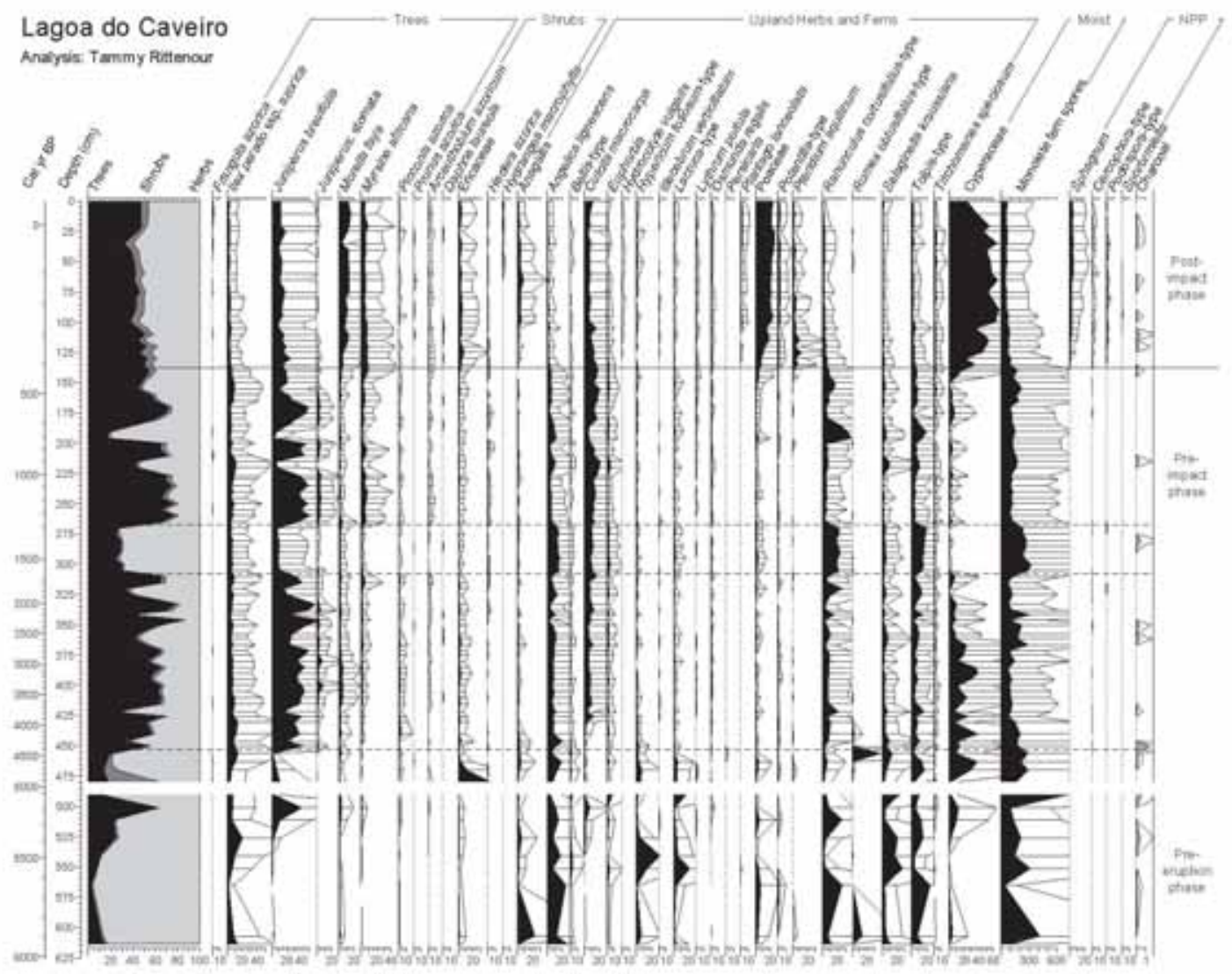

811

812 Figure 4 Pollen diagram from Lagoa do Caveiro on the island of Pico. See caption of

813 Fig. 3 for explanation. The horizontal band represents the division between the central

814 lake core and the marginal core (see Björck et al., 2006). See Appendix S1 for the 815 complete pollen diagram. 


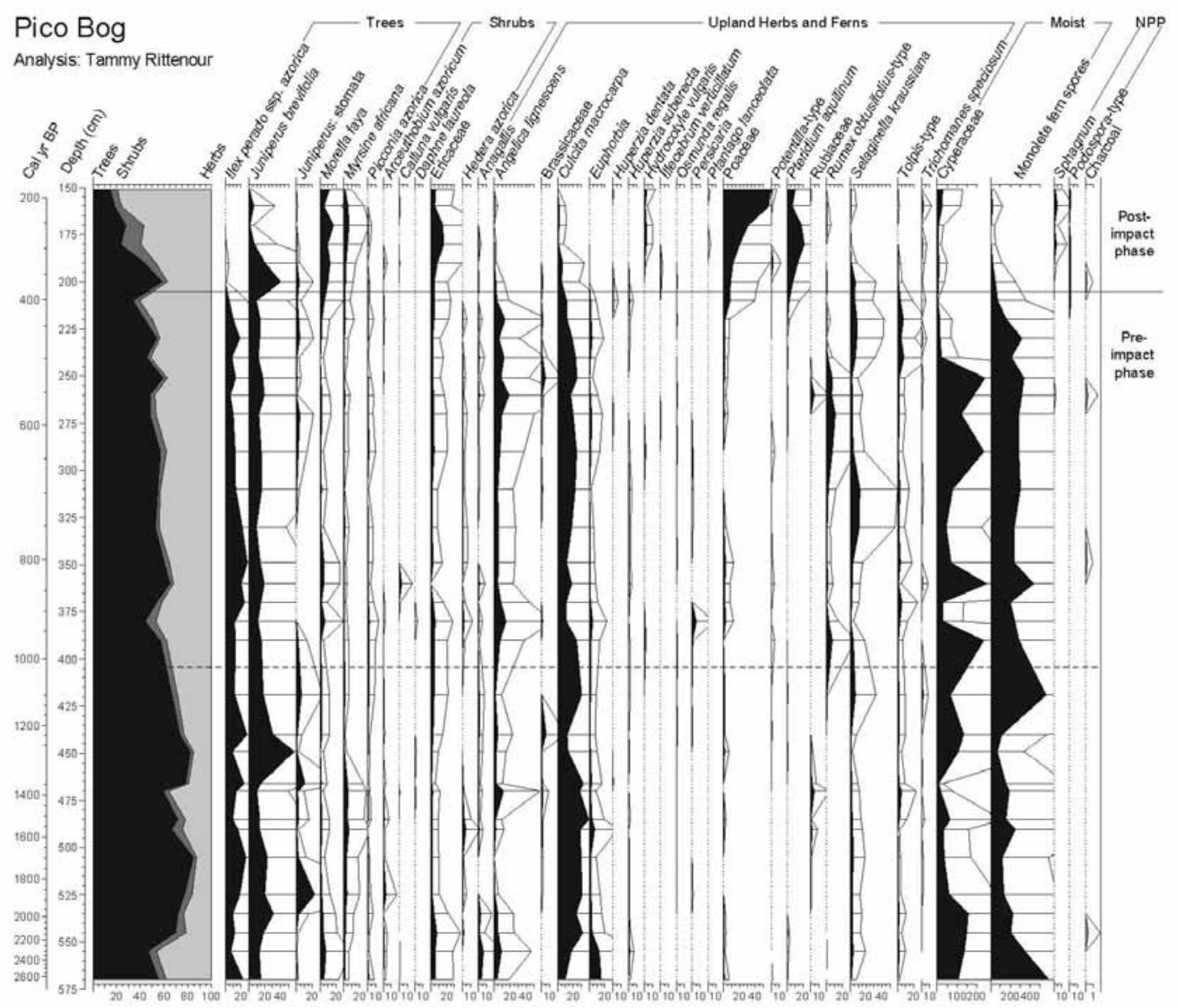

817

818 Figure 5 Pollen diagram from Pico Bog on the island of Pico. See caption of Fig. 3 for 819 explanation and Appendix S1 for the complete pollen diagram. 


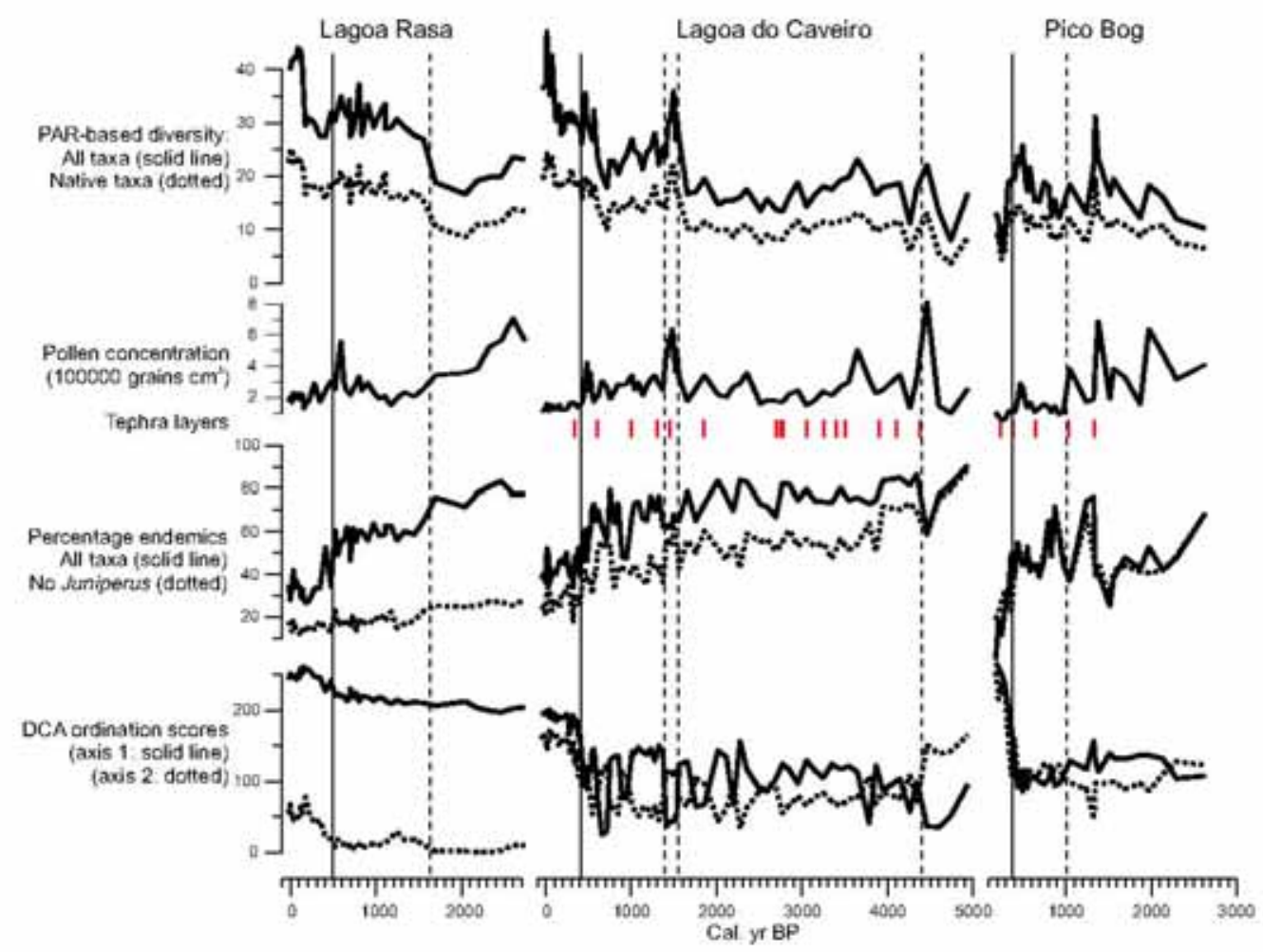

822 Figure 6 Temporal changes in palynological diversity and endemic species

823 representation in the Lagoa Rasa, Lagoa do Caveiro and Pico Bog records from the

824 Azores. Trends are shown in relation to changes in pollen concentrations, tephra layers

825 and ordination scores (detrended correspondence analysis, DCA; Fig. 7). The solid

826 vertical line represents the transition from pre-impact to post-impact (pollen zone

827 boundary) in each record; the dashed vertical lines are other significant zone

828 boundaries. Samples from the marginal core from Lagoa do Caveiro were not graphed

829 due to dating uncertainties in the earliest part of the record (Björck et al., 2006). PAR,

830 pollen accumulation rates. 


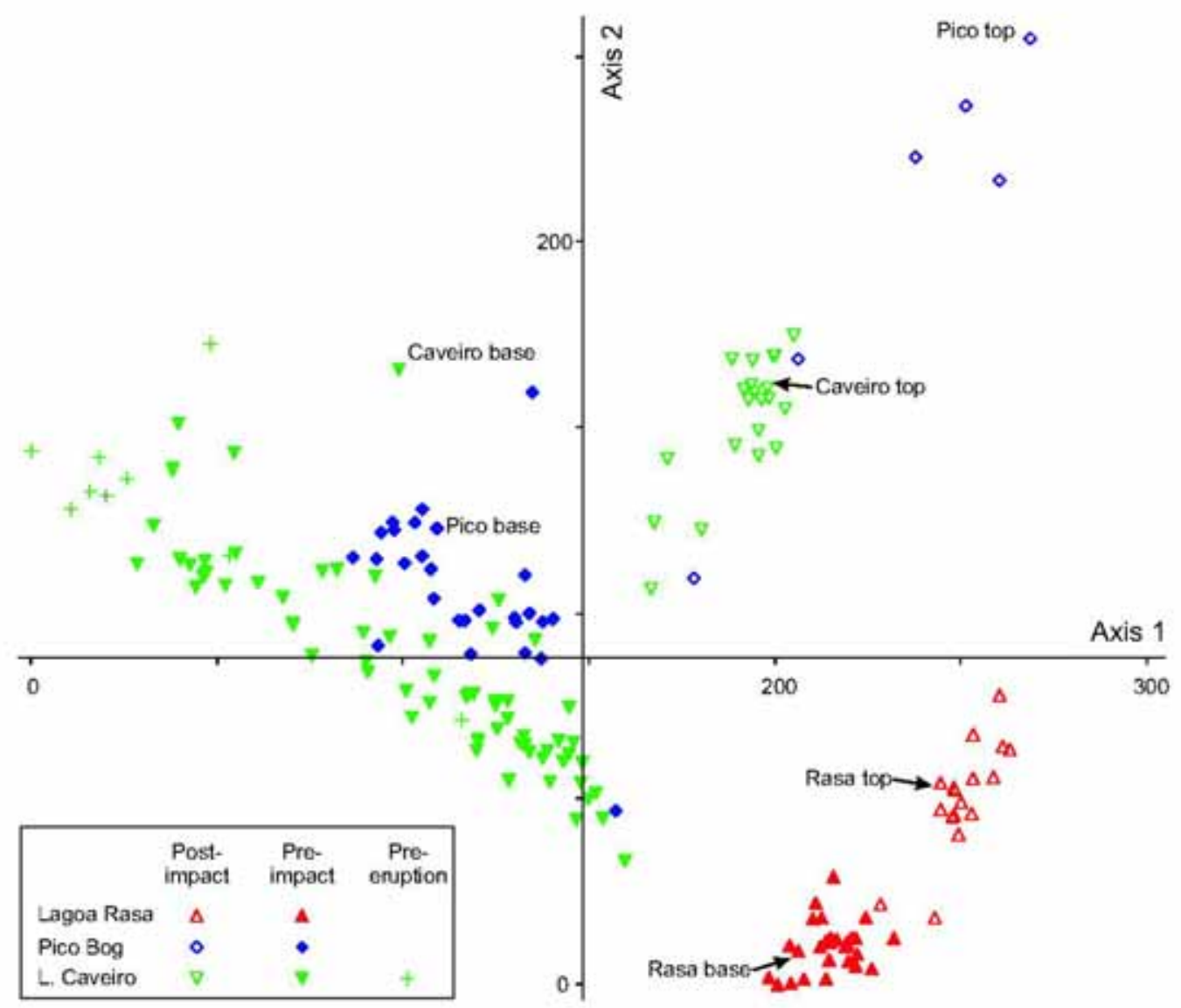

832

833 Figure 7 Detrended correspondence analysis (DCA) result for the Lagoa Rasa, Lagoa

834 do Caveiro and Pico Bog pollen records (Figs 3-5), showing the transition from pre-

835 impact (filled shapes) to post-colonization impacted palaeovegetation (open shapes).

836 The lowermost and topmost samples from each record are indicated and samples from

837 Lagoa do Caveiro prior to a major series of eruptions are also shown. Total inertia

838 value 1.52; axis 1 eigenvalue $=0.36$ (gradient length 2.69); axis 2 eigenvalue $=0.20$

839 (gradient length 2.55). 